\title{
Государство-Коммуна: эксперимент рабочей демократии в России 1918 г. и причины его крушения
}

\author{
Посвящается Ю.В. Цейтлину
}

\section{А.Н. МЕДУШЕВСКИЙ*}

\begin{abstract}
*Андрей Николаевич Медушевский - доктор философских наук, ординарный профессор, факультет социальных наук, Национальный исследовательский университет «Высшая школа экономики». Адрес: 110100, Москва, ул. Мясницкая, д. 20. E-mail: amedushevsky@mail.ru

Цитирование: Медушевский А.Н. (2019) Государство-Коммуна: эксперимент рабочей демократии в России 1918 г. и причины его крушения // Мир России. Т. 28. № 2. C. 63-83. DOI: $10.17323 / 1811-038 X-2019-28-2-63-83$
\end{abstract}

Утопическая идея государства рабочих, приведенная в действие в России после захвата большевиками власти в 1917 г., породила новые типы социальной мобилизации, адаптации, доминирования и политических институтов. Сердиевину этого эксперимента составляла кониееция профсоюзов как формы непосредственной демократии, которая потенцииально могла трансформироваться в форму Государства-Коммуны, основанную на самоуправлении, коллективном производстве и распределении собственности, благ, соичальной ответственности между широким спектром рабочих союзов.

В социологической литературе и огромной интернациональной историографии русской револючии этот социальный эксперимент всегда являлся предметом тщательного анализа как редкий, даже уникальный, исторический пример осуществления абстрактной синдикалистской концепциии бесклассового общества - нового социального контракта, основанного на кооперации и солидарности, а не на бюрократическом контроле. Эта форма правления интерпретировалась как содержательная историческая

1 Юрий Владимирович Цейтлин (1921-2003) - историк рабочего и профсоюзного движения, работавший сотрудником ИНИОН РАН. Беседы с ним оказали существенное влияние на формирование взглядов и научных интересов автора. Ю.В. Цейтлин оставил подробную картотеку выписок из архивных источников и литературы по истории профсоюзного движения в революционной России. Материалы данной картотеки использованы при подготовке настоящей статьи. 
альтернатива традиционному буржуазному государству с такими его главными институтами, как парламентаризм, разделение властей и независимая судебная система. В некоторых современных левых теориях этот эксперимент выступает как модельный - успешный, последовательный и эффективный на начальной стадии (в период так называемого военного коммунизма 1918-1920 г2.), но пересмотренный и окончательно отвергнутый в последующий период бюрократического коммунизма - однопартийной гегемонии и сталинской диктатуры. Чтобы оценить научную иченность подобных утверждений, автор провел детальный анализ приниипов, исходных форм и результатов рабочего самоуправления в период его непосредственного формирования (1918 г.), основанный на изучении многочисленных и ценных первичных источников - стенограмм и протоколов ичентральных и местных профсоюзов (старых и новых), представляющих сочиальную, профессиональную и административную стратификацию русского революциионного общества в процессе его формирования.

Центральный пункт авторской аргументации состоит в том, что так называемая деградация рабочего самоуправления в Советской России коренилась скорее во внутренней трансформации союзов, нежели во внешнем давлении на них или стратегических ошибках. С самого начала револючионные профсоюзы не были аналогами регулярных социал-демократических профсоюзов западного типа, они имели иное, более традиционное социальное происхождение, играли другую роль в социальной трансформации. Комбинация внутренних и внешних факторов этой трансформаџии создала институциональные основы для формирования нового социального неравенства, развития олигархических тенденций в советских профсоюзах и новой трудовой бюрократии. Большевистская партия просто использовала, формализовала и направила этот тренд, но не она его создала. Это означает, что весь эксперимент по конструированию рабочей демократии как новой формь управления изначально оказался фундаментально нереализуем и должен быть отправлен в музей всех утопических проектов человечества.

Ключевые слова: русская революция, коммунизм, синдикализм, анархизм, социальная утопия, рабочая демократия, трудовые конфликты, социальная мобилизация, социальная стратификация, протест, отклоняющееся поведение, иерархия, олигархия, бюрократия, массы и лидеры

Одним из типичных проявлений социальных революций нового и новейшего времени становится утопическая идея непосредственной демократии - создание государственности нового типа, основанной на передаче власти от чиновников к так называемым народным массам или их представительным организациям - различным советам, хунтам, комитетам, профсоюзным организациям, якобы способным не только разрушить традиционное ненавистное «бюрократическое» государство, но и создать новую, «подлинно-демократическую» систему управления, исключающую олигархическое перерождение власти. Попытки установления демократии такого рода, - по Аристотелю, худшей формы правления («охлократии»), - предпринимались неоднократно и во времена античности, и в ходе европейских революций нового и новейшего времени, но получили наиболее четкое выражение в анархическом идеале Государства-Коммуны, положенного большевиками в основу конструирования пролетарской демократии в революционной России, с попытками его неоднократного воспроизводства в ходе последующих революций (мексиканской, испанской, китайской, кхмерской, иранской, ливийской и других). 
Рассмотрим с этих позиций малоисследованный эксперимент рабочей демократии, последовательно осуществлявшийся в России после захвата большевиками государственной власти в октябре 1917 г. и особенно после насильственного роспуска Всероссийского Учредительного собрания в январе 1918 г. В период Гражданской войны, в ходе разработки Конституции РСФСР 1918 г. и создания основ советского политического режима идея Государства-Коммуны стала отправной точкой социального проектирования, прошла весь цикл развития - от восторженного признания до полного крушения, а ее практическая реализация потребовала выработки особых организационных форм профсоюзного движения, претендующего на реальную политическую власть в стране.

Метод настоящего исследования - когнитивная история, т.е. реконструкция информационной картины общества или отдельных его групп, определявшей типы социальной и когнитивной адаптации индивидов и меняющуюся мотивацию их социального поведения [Казаков, Румянцеева 2011]. Его объект - влияние коммунистической утопии Государства-Коммуны на формирование и динамику организационных форм в профсоюзном движении России в 1918 г. Источниковая база - стенограммы и протоколы съездов, конференций и собраний профсоюзов разного уровня (и сопутствующие документы как официального, так и личного происхождения), отложившиеся в их архивах, которые рисуют во многом иную картину, нежели та, что предстает из опубликованных отчетов об их деятельности (и последующей чрезвычайно объемной официальной советской историографии). Информация этих документов обобщена в картотеке, составленной Ю.В. Цейтлиным на протяжении его жизни и переданной автору в частном порядке (около 100 каталожных ящиков); ее материалы никогда не публиковались, а ссылки на них затруднены как характером оформления (это карточки с выписками из документов), так и устареванием имеющихся (часто фрагментарных) указаний на местонахождение источников (нумерация архивных фондов и дел с тех пор неоднократно изменялась). Тем не менее данные материалы отражают совокупность источников по проблеме, позволяя репрезентативно судить о структуре и динамике организационных форм в профдвижении 1918 г. и поднять ряд дискуссионных тем.

Как представляется автору настоящей статьи, следует ответить на вопросы, до сих пор не получившие однозначного решения: до какой степени данный эксперимент действительно являлся самостоятельным проектом рабочего самоуправления; каковы были его содержательные параметры и вклад в формирование политической системы; почему он потерпел крушение - связано ли это с концептуальными противоречиями, особенностями исторической ситуации или ошибками реализации; наконец, каковы были способы осуществления замысла, его эволюция и результаты.

\section{Идеологические основы эксперимента рабочей демократии}

В основе эксперимента лежала идея непосредственного перехода к коммунизму в форме Государства-Коммуны, где рабочие станут не только осуществлять контроль над производством, но и непосредственно управлять государством. Приверженность этой идее изначально определила очень сильный анархо-синдикалистский 
компонент в идеологии всех левых партий, включая большевиков, повлиявший на различные проекты конструирования нового государства и его правовое оформление. В первых проектах Конституционной комиссии 1918 г. формами его организации выступали единая Коммуна, советская федерация территориальных коммун, выражавшая интересы различных социальных групп, и федерация профсоюзов, являвшая представительством производственных объединений [Медушевский 2017].

Механизм установления коммунистического строя схематично усматривался большевиками в осуществлении мер антиэлитарной направленности - разрушении административного аппарата старого бюрократического государства и подавлении правящих классов; проведении национализации средств производства; установлении профсоюзной демократии, т.е. наделении профессиональных объединений рабочих функциями институтов государственной власти и управления; введении рабочего контроля над производством (рассматривавшегося первоначально не как форма управления промышленностью, но как инструмент перехода к рабочему самоуправлению); создании новой системы представительных институтов. Наиболее последовательными сторонниками этих идей выступали анархосиндикалисты, эсеры-максималисты, левые коммунисты, позднее представители «рабочей оппозиции», децисты - своего рода «бешеные» русской революции. В самом большевизме восприятие рабочей демократии трансформировалось по мере эрозии его мессианского потенциала и усиления репрессивно-охранительного вектора [Медушевский 2013]. Обращает на себя внимание эволюция взглядов Ленина и его ближайшего окружения - от полного принятия идеи Государства-Коммуны (как непосредственного управления рабочих) накануне и во время октябрьского переворота к ее пересмотру в пользу советской модели (осень 1918 г.) и позднейшему последовательному отказу от нее как утопической (в 1920-е гг.) в рамках реализованной советской модели однопартийной диктатуры [Медушевский 2015].

Оценки этого эксперимента оказались крайне противоречивы. Конструкция рабочей демократии и контроля над производством рассматривалась большинством аналитиков как анархическая. Кадеты видели существо большевистского переворота в «государственном самоубийстве государственного народа» [Струве 1921, с. 19], причины «печального исхода» революции обнаруживали в общей «слабости русской государственности» и преобладании в стране «безгосударственных и анархических элементов» [Милюков 1921, с. 12], а новую советскую хозяйственную систему определяли как «паразитарную». Всеми подчеркивался синдикалистский тип национализации промышленности, завершившийся «пролетарской анархией» [Прокопович 1923, с. 15]. Соответственно переход от рабочего контроля к управлению выступал как «типично анархический раздел промышленности между отдельными группами рабочих» [Далин 1922, с. 36]. Социал-демократы (меньшевики) видели рабочий контроль не более как проявление революционной эйфории и «анархически-мелкобуржуазное отклонение от марксизма» [Суханов 1923, с. 171-172]. Этот взгляд на экономические эксперименты большевизма как спонтанное проявление анархо-синдикализма утвердился и в западной социал-демократии [Kaytsky 1918].

Компетентные наблюдатели показали полный провал попытки большевиков осуществить национализацию промышленности с использованием рабочего контроля, определяли его как катастрофическое преобразование, считали его результатом торжество синдикализма, анархистских принципов и дестабилиза- 
цию экономики [Prokopovich 1924, p. 10]. В западной историографии эксперимент рабочего контроля рассматривался как спонтанное выражение анархо-синдикализма масс, тактически использованный большевиками для захвата власти [Avrich 1963, pp. 48-60]. В целом он оценивался как провал, во всяком случае, с точки зрения декларированных идеологических целей [Conquest 1967; Brinton 1970]. Э. Карр констатировал, что никто из большевиков не смог предугадать, что захват рабочими фабрик совпадет с установлением социалистического порядка [Carr 1985, pp. 78-79]. В итоге профсоюзы полностью утратили свою идентичность, в конечном счете став частью партийно-государственной машины, о чем свидетельствовали как русские [Загорский 1925; Гарви 1958], так и иностранные [Dunn 1928; Koch 1932] наблюдатели и последующие аналитики властных отношений в советских профсоюзах [Sorenson 1969; Brugmann 1972].

Замыслив реализовать на практике идеал Коммуны, разработчики Конституции РСФСР 1918 г. столкнулись с проблемой определения форм рабочей демократии. Но она по-разному интерпретировалась сторонниками коммунитаризма (создание государства на основе представительства от региональных коммун), анархо-синдикализма (анархистами и эсерами-максималистами, выдвигавшими принцип образования государства по профсоюзному принципу), рабочего самоуправления, позднее «рабочей оппозиции» (провозглашавшей передачу управления народным хозяйством «всероссийскому съезду производителей», объединенных в профсоюзы, которые должны избирать центральный орган, управляющий всем народным хозяйством страны), троцкистами (уже в 1918-1919 гг. выступавшими, как, например, А. Гольцман, за тотальное огосударствление профсоюзов и подчинение их задачам военно-хозяйственной мобилизации) и большевиками ленинского типа (видевшими в профсоюзах инструмент направленной социальной манипуляции). Большевики (в отличие от меньшевиков и эсеров) никогда не разделяли тезиса о нейтральности профсоюзов, рассматривая их скорее как мобилизационный институт, обозначаемый известной фразой К. Маркса о «школе коммунизма».

Утопическая вера в возможность рабочего класса самостоятельно управлять государством (в рамках федерации профсоюзов) и производством через совнархозы (органы управления промышленностью) и фобзавкомы, а также систему рабочего контроля (без обращения к профессиональным или «буржуазным» спецам) была характерна для коммунистических авторов именно в 1918 г. [Осинский 1918; Милютин 1918; Ломов 1918]. В дальнейшем она сменилась представлением о вынужденном, переходном характере этих мер в условиях военного коммунизма [Цылерович 1921; $\Phi u н ~ 1922]$, которые, вопреки очевидности, будто бы никогда не рассматривались как форма непосредственного утверждения коммунизма во всемирном масштабе [Ларин 1920; Криимман 1924; Рожков 1926]. Этот постулат был всецело принят в советской литературе [Панкратова 1954; Шарапов 1977; Виноградов 1983]. Анархические корни большевизма, впрочем, постепенно утрачивали значение при столкновении с реальностью [Игнатенко 1971]. Как ни парадоксально, основным аргументом противников рабочего самоуправления стала кампания по огосударствлению экономики (или так называемой национализации производства и банков), остро поставившая вопрос о том, кто реально осуществляет контроль над ним.

Проблема выбора между однопартийной диктатурой и институционализацией профсоюзной демократии на начальном этапе не осознавалась столь четко, как в последующий период, сделав возможным сам эксперимент рабочей демократии. 
Эти установки определили изначально отрицательное отношение большевиков к традиционному тред-юнионизму, сводящему цели профсоюзного движения к техническому обслуживанию членов корпорации и защите их интересов, что ведет к перерождению рабочей демократии и ее олигархизации. Уклонение от данного тренда, вполне подтверждаемого социологией формальных организаций и предшествующим опытом, предполагало наделение профсоюзов более значимыми общественными функциями вплоть до последовательной передачи под их контроль управление экономикой.

\section{Профсоюзы как машина производства и управления}

Согласно идеологии коммунизма, только труд дает право на потребление, а потому (считали русские синдикалисты) все население должно быть организовано по роду своих профессий и занятий. Эволюция доктрины большевизма в вопросе о рабочей демократии связана с экономическими процессами и прежде всего с регулированием трудовых отношений. Принцип обязательности труда для всех трудоспособных граждан был провозглашен III Всероссийским Съездом Советов в январе 1918 г. В принятой съездом «Декларации прав трудящегося и эксплуатируемого народа» было сказано, что «в целях уничтожения паразитических слоев общества и организации хозяйства вводится всеобщая трудовая повинность» ${ }^{2}$. Это положение вошло затем и в первый раздел Конституции РСФСР 1918 г., а во втором разделе провозглашалось: «РСФСР признает труд обязанностью всех граждан Республики и провозглашает лозунг: “Не трудящийся да не ест!"»”. «Кодекс законов о труде», принятый уже в начале Гражданской войны (10 декабря 1918 г.) устанавливал трудовую повинность как основную форму привлечения к труду, жесткое централизованное нормирование условий труда вместо регулирования коллективными договорами, натурализацию большей части заработной платы, замену социального страхования, основанного на страховых взносах предприятий и учреждений, социальным обеспечением, основанным на прямых ассигнованиях, выделяемых государством в централизованном порядке по смете Народного комиссариата труда [Вопросы труда в СССР 1958, с. 322-323]. Большевиками были приняты меры к выявлению и использованию всех резервов рабочей силы: введение трудовой повинности; трудовых книжек для нетрудящихся; преобразование бирж труда (как институтов регистрации безработных) в управления по учету и распределению рабочей силы; принудительная мобилизация лиц, не занятых общественно-полезным трудом, к общественным работам [Венедиктов 1957; Гимпельсон 1974, с. 133].

Так возникал «профсоюзный коммунизм» в стиле анархо-синдикалистских доктрин, восходящих к Фурье, Оуэну и Прудону. Принадлежность к профсоюзу выступала не только правом, но и обязанностью, предполагая принудитель-

\footnotetext{
2 Декларация прав трудящегося и эксплуатируемого народа. Принята III Всероссийским Съездом Советов 12 января 1918 г. // СУ РСФСР. 1918. № 15. Ст. 215.

3 Конституция (Основной Закон) Российской Социалистической Федеративной Советской Республики. Принята V Всероссийским Съездом Советов на заседании от 10 июля 1918 г. // СУ РСФСР. 1918. № 51. Ст. 582.
} 
ное членство. «Таким путем, - считали его сторонники в 1918 г., - мы овладеваем всей массой в целом. В наших руках оказывается вся машина производства». Необходимо поэтому издать «закон об обязательной записи всех и каждого в тот или иной профсоюз». «Это не значит, - разъясняли они, - что нужно записывать силой, но предполагает, что каждый из незаписавшихся рискует испытать те или иные издержки распределения продуктов и товаров». Предписывалось, следовательно, косвенное административное управление обществом через профсоюзы. В результате сформировалась корпоративистская модель общества: все социальные группы привязаны к определенной корпорации (профсоюзной секции), вводится система репрессий (при сокращениях нечлены профсоюза увольняются в первую очередь) и поощрений (о них - ниже). «Положение рабочего, не приписанного ни к какому союзу, - отмечали современники, - делается критическим» (1918 г.).

Дискуссия по этому поводу выявила сложные вопросы: что делать с теми, кто не желает участвовать в профсоюзах; как сбалансировать моральное и экономическое воздействие на уклонистов с целью изъятия их из союзов и удаления из общественной жизни пролетарской среды; следует ли принимать в профсоюзы администраторов (теоретически противников рабочих); не спровоцирует ли принудительное членство бюрократизацию и коррупцию; не приведет ли это к деградации союзов и росту конфликта рабочих и служащих, бойкоту профсоюзов.

Все эти сомнения были отвергнуты в 1918 г. Ответы, предложенные комитетами, были взяты из репрессивной логики революционной трансформации: нельзя управлять финансами и контролем, если не будет полного членства всех рабочих; нужно принять решение о том, что на работу принимаются только члены профсоюза; все рабочие, не вступившие в союз к определенному сроку, должны быть уволены; при сокращении штатов и уплотнении работники, не вступившие в профсою3, увольняются; вводится система чисток - те, кто желал бы «тянуть социальный строй к старому порядку», становятся объектом проработки коллективом; лица, нарушающие устав профсоюза, автоматически изгоняются из него, а следовательно, теряют работу; антитезой коррупции и бюрократизации становится право отзыва избранных депутатов собраниями. Нейтральность профсоюзов, ранее отстаивавшаяся социал-демократией как в Европе, так и в России, после революции превратилась в химеру. Политическая активность масс получила четкую квалификацию: 1) стихийные выступления с политическими требованиями; 2) выступления под политическими лозунгами партии; при этом 3) политические выступления подразделялись на две группы: а) с негативными политическими требованиями, б) с позитивными политическими требованиями. В интересах коммунизма, по мнению большевистских комитетов, были уместны не стихийные, а лишь дисциплинированные проявления активности в рамках профсоюзов, лояльных власти.

Перестройка профсоюзов началась сразу после октябрьского переворота. Этот процесс означал, что постановления профсоюзов стали проводиться принудительным путем; классовая деятельность была заменена «механическим воздействием вооруженной руки». На практике это отражало следующую позицию комитетов: 1) союзы - это принудительный орган; 2) сила закона признается за всеми постановлениями союза, в том числе и нечленами союза; 3) проводится слияние союзов с хозорганами; 4) союз управляет производством; 5) рекомендуется подчинение союзов госвласти, в частности, путем превращения в отделы советов. Доминирующие точки зрения об огосударствлении оставляли небольшой коридор выбора 
вариантов: одним оно виделось в форме прямого превращения союзов в органы государственной власти; другие думали, что оно означает передачу союзам законодательных функций; третьи воспринимали его в виде принудительного членства; четвертые полагали, что союзы будут превращены в секции при советах; пятые представляли себе огосударствление в виде механического подчинения союзов через специально назначаемых для этого комиссаров. Но в любой из схем индивид терял право выбора вне корпоративистской профсоюзной машины.

\section{Структура и динамика организационных форм}

Основными факторами, определяющими структуру профобъединений и специфику их деятельности, в литературе признаются следующие: территориальный, обозначающий столицы, промышленные города или географически удаленные локальные центры, вынужденные самостоятельно определять повестку деятельности; производственный, уточняющий принадлежность союзов к определенным отраслям промышленности, более или менее важным (от профсоюзов металлистов до кустарей); профессионально-статусный, описывающий деление союзов в соответствии со статусом профессии и степени вовлеченности в нее (от железнодорожников до артистических профобъединений или их совсем экзотических разновидностей, как например, проституток, официантов или гостиничных швейцаров); административный, определяющий ведомственную принадлежность профсоюзов (печатников, работников просвещения, служащих и т.п.); политический, фиксирующий доминирующее влияние определенной идеологии или партийной фракции в руководстве. В рассматриваемый период соотношение этих факторов было подвижно: они находились в процессе формирования и взаимодействия, при этом общая картина оставалась очень пестрой.

Соотношение профессионального и производственного принципов организации профсоюзов представлялось весьма динамичным. Общие рекомендации состояли в образовании профсоюзов по производственному (а не территориальному принципу); в их укрупнении с последующим включением в ВЦСПС; в проявлении скептицизма в отношении так называемых комбинированных союзов (союз союзов), которые могли оказаться нелояльны власти; в предписании не образовывать и, во всяком случае, опрометчиво не принимать в союзы служащих, к которым относились с сомнением с классовой точки зрения; в введении автоматического вычета взносов из зарплаты (в сознании совбюрократии постоянно присутствовал ВИКЖЕЛЬ ${ }^{4}$ как ориентир опасности). Общие или объединенные союзы подвергались критике, поскольку их существование противоречило производственному принципу и вводило то, с чем боролись коммунисты, считавшие, что нужно создавать централизованные союзы или приписывать рабочих через местные советы профсоюзов к центральным или областным профсоюзам. Пока в профсоюзах не утвердился производственный принцип построения, допускалось в качестве временной меры вхождение в них фабрично-заводских служащих. Со временем предполагалось объединить всех служащих в единый союз служащих, отделив их от

4 Всероссийский исполнительный комитет железнодорожного профсоюза (1917-1918 гг.). 
рабочих. Констатировалось, что выделение секций в смешанных профсоюзах не логично, ибо с ожидаемым огосударствлением профсоюзов все они станут союзами работников госпредприятий.

Тенденции к укрупнению и разукрупнению профсоюзов являлись выражением доминирующей политической линии: даже когда этого не требовал производственный принцип, укрупнение выступало одним из методов централизации, в любом варианте имевшей в данный момент времени политический аспект. Понятие укрупнения было применимо к профсоюзу, объединившемуся самостоятельно: как бы мала ни была отрасль производства, обязательным условием оставались наличие предприятия, на котором представлено большинство занятых в данной профессии (т.е. специализированные предприятия), и соответствие профессии направлению деятельности учреждения. В отдельных случаях речь шла о ликвидации цеховых профсоюзов: в 1918 г. критерий производственного профсоюза трактовался, по-видимому, более широко, не в последнюю очередь из-за политических соображений. Прослеживалось стремление большевиков слить профсоюзы или, во всяком случае, их руководство воедино в рамках общей тенденции к централизации и бюрократизации. В этой тенденции имелся определенный нюанс, состоящий в позиции крупных и мелких профсоюзов, профсоюзов и их секций, союзов служащих и ИТР, различное отношение к объединению, в котором растворялась их специфика. Тем не менее централизация происходила и сверху (от ВЦСПС), и снизу (от активистов), поскольку руководство мелких профсоюзов рассматривало интеграцию в более крупные структуры как источник выживания.

Речь шла не только об укрупнении, но и разукрупнении профсоюзов - создании производственных секций по важнейшим отраслям промышленности с целью привлечения большего числа рабочих к решению производственных вопросов. Одновременно были представлены предложения о замене производственных секций секциями рабочих ведущих профессий, возглавляемых выборными правлениями без платного аппарата. Одни выступали за объединение в профобъединении всех (от рабочего до специалиста высшей квалификации), а не за их разделение (что официально рассматривалось как ошибка); другие, напротив, выступали за дифференциацию с учетом различия социальной природы профобъединений. ВЦСПС принимал союзы госслужащих с совещательным голосом, поскольку они носили непролетарский характер, являлись социально чуждыми, ненадежными и должны были прежде изменить свою социальную сущность, отказавшись от нейтрализма и приняв позиции пролетариата.

Любая мера по расширению компетенции высшего федерального органа, естественно, могла идти за счет ограничения автономии профсоюза: таким образом, в 1918 г. объективно подготавливалась основа для ликвидации возникшего ранее профсоюзного федерализма. Но документы фиксировали непосредственно компетенцию федеративного органа, упоминали об организации автономных профсоюзов. Не всегда было ясно, идет ли здесь речь о нарушении автономных прав низовых федеративных органов или о покушении на прерогативы высшего органа. В таких случаях вопрос следовало решать в зависимости от содержащейся в тексте формулировки - автономия в отношении «федерального объединения» (в частности, по организационным вопросам). Здесь были взаимосвязаны как нормативное решение, так и политическая практика, в частности, нарушение федеральным органом ограничения автономии союзов-членов. В 1918 г. в ВЦСПС было принято 
принципиальное решение - упразднить орготделы при отделениях союза с концентрацией их наверху (ВСЖС).

В 1918 г. основными предметами дискуссии в профсоюзах являлись характер объединения, представительства (пропорциональное или нет), основы слияния, уставные документы, съезды и конференции; шли споры о представительстве и датах созыва съездов, формировании повестки дня: кто и как формулирует вопросы, подбор ораторов, отношение профсоюзов к посекционным выборам. При неясности критериев разделения пролетарских и непролетарских партий существенное значение имели социальный профиль профсоюзов (металлистов, кожевников, табачников, печатников, пищевиков, текстильщиков, работников искусств, швейников, аптекарей, медиков, почтово-телеграфных служащих, госслужащих, работников просвещения, фабрично-заводских служащих, булочников, железнодорожников, химиков и прочих) и их съезды, собрания уполномоченных, лидеры и дебаты. Определенные социальные группы, проявлявшие активность, рассматривались как недостаточно лояльные (инженеры, мастера, конторщики, чертежники, служащие, финансовые служащие, телеграфные служащие, акцизные служащие, банковские служащие). Союзы служащих финансово-кредитных учреждений, таможенных служащих и т.п. действительно противостояли самопровозглашенным институтам власти (Ревкомам, «пятеркам» и «тройкам»), использовали традиционные формы протеста (забастовки, фракции, публичные выступления), оперируя важными финансовыми институтами (деньгами, займами, казенной палатой).

Ассоциация или диссоциация организаций - это главная социологическая проблема переходного периода. Вопрос об объединении или отказе от него был связан с политическим составом организаций, однако в источниках (как опубликованных, так и архивных) можно обнаружить слишком мало сводной информации по данному вопросу. Систематизация организационных вопросов не выявляет единой картины по разным видам профсоюзов. В отношении финансовых союзов можно констатировать, что это по преимуществу объединение ведомственных союзов; это относится и к союзам служащих, которые обсуждали вопрос об объединении в течение всего 1918 г., но так и не объединились. Оргструктура профсоюзов железнодорожников демонстрировала самые путаные союзы, причем эта путаница возникала из-за параллельного сосуществования двух типов союзов территориальных и профессиональных, при этом первые одновременно являлись и административными органами, управляющими дорогами и контролирующими деятельность профессиональных союзов, хотя смысл их взаимоотношений на каждой дороге был разным и зависел от партийного состава, который в источниках отражен фрагментарно и не позволяет сделать определенные выводы. Объединение фельдшеров и врачей в единый союз проходило одновременно с другим интеграционным процессом - объединением двух союзов фельдшеров - настоящих («школьных») и прошедших краткосрочные курсы («ротных»), к тому же они имели различный партийный состав: врачи, вероятно, эсеры и кадеты, «школьные»меньшевики, «ротные» - большевики.

В источниках отражен социально-психологический процесс слияния профессиональных групп с различной партийной принадлежностью. Конфликтные отношения «рабочих» профсоюзов и профсоюзов совслужащих, т.е. администрации, представлены особенно четко в ходе решения жилищного вопроса - переселения рабочих в квартиры городских служащих (так называемое уплотнение). 
Эти противоречия отражали, с одной стороны, неприязнь рабочих, особенно подмосковных фабрик, к «белой кости», а с другой, нежелание государства на данном этапе вступать в прямой конфликт с профсоюзами служащих, из чего следует, что продуманная и рафинированная система методов давления на членов профсоюзов, сочетающая кнут и пряник, еще не была создана.

\section{Селекция профсоюзной массы: система доступа, фильтрация, иерархия}

Поиск формирующимся режимом социальной поддержки оборачивался сегрегацией состава профдвижения - дискриминацией на стадии приема в профсоюзы. Шкала приоритетов дискриминации включала в себя заработный ценз; недопущение мастеров и служащих; политическую, религиозную, гендерную дискриминацию; квалификационный ценз, причем интенсивность дискриминации в разных типах профсоюзов была неодинакова (высокая, средняя, низкая).

Следует отметить, что зависимости между уровнем профессиональной дискриминации и частотой съездов не установлено, причем дискриминация была сильнее в старых профсоюзах, чем в более молодых. По свидетельствам экспертов того времени, более открытые союзы были полны «балласта»: поскольку их руководство стремилось к массовости, туда шли все, кто стремился обрести привилегии (полтора пуда продуктов как льгота за вступление). Обратное стремление заключалось в закрытии профсоюзов и пресечении легкого вступления, в чистке или фильтрации членов союзов, института кандидатов в члены и споре о том, имеют ли они право участвовать в выборах совета. В этой связи показательны дебаты о мотивации отказа в приеме новых членов: речь шла не об исключении (вряд ли комитет стал протестовать, если бы мотивом был вопрос о принадлежности к рабочим, а не к мастерам), но о «неприятии» (имелась в виду не прямая санкция за какой-то проступок, а отказ в приеме по классовым соображениям).

Решающим был статус социальной принадлежности, фактически закладывающий новые принципы стратификации и, следовательно, порождавший источник неравенства [Шкаратан 2012]. С этих позиций обсуждался вопрос о допущении нелояльных категорий - представителей групп, верных старому начальству (например, бывших штрейкбрейхеров и т.п.). Для четкого распознания «своих» при записи новых членов применялась экспертиза: нужно было предъявлять удостоверение о работе на соответствующем предприятии, рекомендации от двух членов союза и картонные бирки, где отмечались посещения собраний. При поступлении в союз взимался взнос; некоторые профсоюзы условием членства выдвигали требование наличия определенного (трехлетнего) стажа; вводился и кандидатский стаж (например, у работников искусства); из союзов изгонялись лица, не имевшие стажа и попавшие в него случайно; создавались специальные аттестационные комиссии для исключения приема нежелательных элементов; Всероссийский союз радиоработников принимал новых членов только по экзаменам. Однако некоторые профсоюзы (например, РАБИС $)$ позднее ставили вопрос о пересмотре для работников в области искусства принципов, определяемых классовой принад-

5 Союз работников искусств. 
лежностью, поскольку старые признаки, вызванные обострением форм классовой борьбы, меняют свою форму и содержание, а их формальное применение может стать тормозом, мешающим государственному строительству в области искусства.

Помимо этого, трудноразрешимым оказался вопрос о вступлении в союз предпринимателей. В документах 1918 г. понятие «предприниматель» не всегда, по-видимому, было равнозначно «работодателю» (использовалось понятие «антрепренер», но оно также не было тождественно «предпринимателю»). В ряде случаев понятие «предприниматель», очевидно, распространялось на всех занимающихся индивидуальной трудовой деятельностью, в других - исключительно на использующих наемный труд и не работающих по найму. Традиционно (до революции) профсоюзы включали только наемных работников, а не нанимателей, и для союза врачей и фельдшеров это создавало неразрешимые проблемы. Различие между предпринимателем и рабочим здесь могло быть условно: в отличие от других отраслей, подавляющая часть врачей-«предпринимателей» это, очевидно, лица, имеющие одного или двух ассистентов или зубного техника, т.е. кустари-неодиночки.

Вопрос о том, могли ли вообще кустари быть членами профсоюза, получал противоположные решения: с одной стороны, как мелкие частные собственники не могли, с другой, - могли, но без использования наемного труда. Другая причина сомнений - невозможность профсоюза контролировать их труд, что делало их сомнительными с точки зрения классовой природы. Как правило, кустарей как «мелких хозяйчиков» не пускали в профсоюзы, но в тех случаях, когда разрешали вступать, им отказывали в праве участвовать в голосовании с решающим голосом. Однако эта политика не была стабильной: в 1918 г. заявлялось, что кустари (например, часовщики, ювелиры) в союз входить не должны; некоторые профсоюзы принимали постановления о непринятии в союз лиц, работающих на себя, на дому (швеи, домохозяйки), но окончательное лишение кустарей права членства в профсоюзах произошло только в 1922 г.

В революционной России дискриминировались все классово, идеологически и даже профессионально сомнительные категории: например, вопрос о вступлении в профсоюз членов артелей (зародышей производственных коммун) обсуждался достаточно долго, поскольку они плохо вписывались в регулярную организацию профсоюзов. Артели, как и кустари (коммерческие предприятия, члены которых прибыль делили между собой), представляли собой маленькие акционерные общества, у которых имелись своя собственность, мастерские и прочее, а потому, как отмечалось в документах, могли «захлестнуть профсоюзы мелкобуржуазной стихией». Еще более негативное решение было принято в отношении лиц свободных профессий, которых запрещали принимать в профсоюз, поскольку они были «насквозь проникнуты консервативной идеологией и в силу своей циничности могли дезорганизовать ряды пролетариата». На тех же основаниях недоверия решено было отказать во вступлении военнослужащим, вернувшимся с фронта, рабочим с пропущенным стажем и поденщикам.

Спорным оставался вопрос о допущении членства служащих, ИТР и административного персонала. Предлагалось отсечение всех элементов, которые по своему служебному положению и административным обязанностям не могли принимать участие в пролетарском классовом профсоюзе; утверждалось, что в соответствующих профсоюзах места администраторам нет. В других профсоюзах им 
все же позволялось становиться членами союзов, но с различными оговорками: обычно речь шла о включении служащих, не занимающих высшие административные должности, т.е. не являющихся бюрократами, но данный принцип противоречил революционной идее выборности всех административных служащих и поэтому должен был быть признан экстрареволюционной мерой.

Дебаты в отношении ИТР выражали столкновение сторонников и противников их включения (связанные, в частности, с отношением к тейлоризму и решением проблемы мотивации труда). IX и X Съезды РКП предрешили проблему их вступления, указав на необходимость привлечения спецов: им было предоставлено право на добровольное вступление в профсоюзы с испытательным сроком в качестве кандидатов. Таким образом, они (в отличие от всей остальной интеллигенции) имели возможность получать классовый паек - продукты, выдаваемые только членам профсоюза. Первый съезд работников просвещения (1919 г.) принял за основу нормативный устав ВЦСПС и обсуждал вопрос об условиях, на которых возможно распространение профсоюзных привилегий на мелкобуржуазную и интеллигентскую среду, а также об особенностях уставов объединений, связанных с идеологическим строительством. Предполагалось, что если принимать эти категории, то только для контроля над ними. Компромисс переходного периода выражался формулой: «пусть это элемент непролетарский, но мы их подчиним себе и в любой момент можем умертвить», что и было воплощено в жизнь в ходе подавления рабочих восстаний и выступлений с участием независимых союзов и оппозиционных партий [Солженицын 1981; Чураков 2007].

Соотношение квалифицированных и неквалифицированных рабочих в профдвижении оказалось достаточно острой проблемой. Классики западного профдвижения С. и Б. Вебб считали, что профессиональная организованность доступна преимущественно квалифицированным рабочим ${ }^{6}$. Но в России была представлена обратная логика, поскольку квалифицированные рабочие воплощали «аристократию», а неквалифицированные или чернорабочие являлись воплощением классового принципа и их включали в приоритетном порядке. Под влиянием коммунистического миража бесклассового общества профсоюзы отказались от своего предназначения - ведения борьбы с заводской администрацией, поскольку в этой логике государство стало рабочим, подавлять рабочих уже некому, а значит, отпала необходимость в защите интересов рабочих.

В 1918 г. осуществление требования всеобщего членства рабочих в профсоюзах стало основой дифференциации рабочей массы по признаку «принятые» и «непринятые», контроля по степени лояльности, а также выстраивания внутренней иерархии по линии допуска к привилегиям, распределявшимся профсоюзным руководством. Эти тенденции определили кастовость советских профсоюзов, параметры которой задавались, с одной стороны, системными ограничениями (меры против проникновения буржуазии и вообще образованных лиц), с другой, направленной фильтрацией членов - жесткой системой рекомендаций (для вступления нужно было получить согласие не только районного собрания, но иногда и партийных органов). Профсоюзы предоставляли индивиду и статус, и экономические привилегии, занимаясь распределением различных прав и карточек на получение

6 Вебб С., Вебб Б. (1900-1901) Теория и практика английского трэд-юнионизма. 2 тома. Перевод с английского В. Ильина (В.Ульянова-Ленина). СПб.: Издательство О.Н. Поповой. 
продуктов, а поскольку карточки давались только членам профсоюзов, некоторые вступали в них исключительно ради этих благ. Дискуссии внутри профсоюзов о выявлении границ соответствующей профессии (например, кого считать медицинскими работниками или учеными) определялись не только решением оргвопросов (распределением по секциям), но элементарной борьбой за выживание, потому что отнесение или исключение из определенной группы автоматически означало перекрытие доступа к соответствующим ресурсам.

Вопрос о размежевании профессиональных групп и их профсоюзных структур имел не только технические, но экономические (тарифная сетка), кадровые, а часто и политические параметры, что создавало цеховой принцип организации рабочей демократии, закладывая основы новой советской иерархии.

\section{Суть и итоги эксперимента: генезис советской профбюрократии}

Идеал рабочей демократии есть порождение революционного мифа, фикция революционной эпохи. Данный феномен никогда не действовал в аутентичной форме, во всяком случае, соответствующей ее теоретической (марксистской или анархосиндикалистской) конструкции, т.е. как автономная (саморегулирующаяся) политическая система. В реальности абстрактная рабочая демократия свелась к определенным формам профсоюзной демократии - попытке наделить профессиональные союзы известными хозяйственно-административными полномочиями в условиях крушения государственности, экономики, возникновения вакуума власти и хаотичных попыток заполнить его спонтанными самопровозглашенными институтами самоуправления в виде советов, профсоюзов и комитетов различной природы и функций. Все эти институты вступили в дарвинистическую борьбу за существование - за право контроля над собственностью, ресурсами и полномочиями.

$\mathrm{B}$ социологической теории второй половины XX в., которая обобщила опыт социальных трансформаций, связанных с переходом от традиционного к индустриальному обществу, убедительно представлены пессимистические выводы о долговременности шансов сохранения демократии в формальных организациях (в частности, в профсоюзах), поскольку структура любой крупной организации по своей сути требует развития бюрократических моделей поведения и содержит имманентную тенденцию к иерархизации и олигархизации [Лиnсет 2015]. Эти выводы подтверждаются на материале изучения российских профсоюзов 1918 г. с учетом отсутствия в них устойчивых функциональных требований относительно демократии и разделения типичных и девиантных практик в рабочем движении. Энергетика распада стабильного экономического уклада в условиях возврата к натуральным формам ведения хозяйства выдвинула на первый план профсоюзы как органы, с одной стороны, опиравшиеся на традиционную демократическую легитимность, с другой, способные на короткий период осуществлять медиацию между рабочей массой и революционными политическими лидерами, которые неожиданно для себя оказались у власти и по существу не имели четкого представления, что с этой властью делать.

Однако выполнение этой функции оказалось несовершенным 1) из-за конкуренции различных центров власти, 2) из-за аморфности и раскола в самом профсо- 
юзном движении (между старыми и новыми союзами, организациями, построенными по различным критериям и прочее) и 3) ввиду генетической неспособности профсоюзов выполнять функции управления производством. В результате начался процесс деградации профсоюзов как органов защиты прав рабочих с их одновременной иерархизацией и бюрократизацией, связанный с наделением их мобилизационными и контрольно-репрессивными функциями и завершившийся позднее их слиянием с государством. Основными вехами на этом пути явились использование профсоюзов для захвата предприятий, создание особых фабрично-заводских комитетов, выстраивание вертикали управления под руководством профбюрократии (инструкторов, освобожденных профработников и профактива), направленно формировавшейся непосредственно в ходе огосударствления экономики.

Профсоюзы 1918 г. выступали не столько в качестве профессиональных союзов в аутентичном смысле, сколько как специфическая организация революционной эпохи со своими характерными в сравнении с другими массовыми организациями (партиями, советами, государственными экономическими органами) особенностями, задававшими формат отношений с ними и особые функции профсоюзов. Эти особенности вырабатывались логикой процессов интеграции и дезинтеграции профобъединений, динамикой их организационных форм, спецификой позиций партийных фракций в союзах по сравнению с позицией партийных центров, решением проблемы «лидеры - масса» в рамках союзов 1918 г. (в том числе взаимоотношением партийных лидеров с профсоюзной массой). Структура и динамика организационных форм определялись четырьмя критериями: 1) политическими целями организации, 2) средствами их достижения, 3) практикой осуществления, 4) последствиями. По результатам исследования правомерно задаться комплексом вопросов: «был ли мальчик», т.е. существовал ли в действительности сам феномен рабочей демократии, и если отдельные ее элементы все же присутствовали, то куда они пропали; связано ли это исчезновение с произволом новой власти большевиков (как обычно утверждается в историографии) или является следствием имманентной логики развития профсоюзов как формальной организации.

Проведенное исследование позволяет сделать вывод, что имел место двусторонний процесс иерархизации (и снизу, и сверху), но он определялся вполне естественной логикой трансформации организационных форм. Объективная тенденция к смене форм непосредственной демократии иерархией получила чрезвычайное ускорение в революционной России в силу ряда исторических факторов: 1) общего международного контекста социального конструирования и преследуемых целей (ориентация на мировую коммунистическую революцию); 2) исторического контекста соотношения целей и средств их достижения (ориентация на эффективность в противоположность справедливости в чрезвычайных условиях гражданской войны); 3) аморфности профсоюзного движения при всей его активности (вопрос об особенностях отдельных союзов - всероссийских центров, организаций Москвы и Петербурга, региональных центров); 4) социально-психологического фактора и его влияния на политику союзов (патерналистски-авторитарная психология масс и лидеров).

После революции произошло постепенное установление контроля профадминистрации над формальными средствами коммуникации профсоюза: их монополизация руководством; отсечение рядовой массы членов союза от нежелательных 
источников информации - как внешней (позиция других союзов), так и внутренней (оппозиционные фракции или группы рабочих); закрепление стереотипов лояльного и нелояльного поведения рядовых членов в отношении лидеров; введение системы поощрений и санкций за нарушения по основным параметрам социализации индивида в союзе (идеология, преданность, управление, активность); целенаправленная селекция и поощрение групп поддержки - «профактива» (для манипулирования съездами и выборами); контроль над мобильностью внутри структуры союза и процессом социализации (получением рядовыми членами первичных навыков политической деятельности), закрепляющий механизмы воспроизводства структуры организации и лидерства; а также долговременное пребывание избранных лидеров у власти в профдвижении. Качественное обособление профбюрократии утверждалось особым местом в иерархии, статусом и властью, т.е. возможностью перераспределения ресурсов, включающих в себя не только зарплату, но и распределение трудовых обязательств, продуктов, жилья, дров и других жизненно-важных благ между членами профсоюза. Решающим критерием статуса освобожденного профработника стали не выборы, а поддержка иерархических институтов.

С этих позиций возможна достоверная оценка судом истории (pro, contra, приговор) целей и средств российской рабочей демократии в длительной исторической перспективе. Рабочая демократия в России была уничтожена не потому, что переродилась в результате позднейших бюрократических искажений, как принято считать в историографии, поскольку видоизмениться может только то, что уже появилось. Тенденция к олигархизации революционных профсоюзов - не деформация, а имманентная характеристика общей логики их развития как формальной организации. Эта тенденция менее четко выражена в дореволюционный период, когда профсоюзы впервые возникли на исторической арене (после Первой русской революции) или выступали фактором разнонаправленного партийно-политического самоопределения рабочих (в период Февральской революции), но определяющей она стала после октябрьского переворота и огосударствления экономики уже в 1918 г. Большевики лишь возглавили этот тренд (усиленный во многом сохранением общинно-патерналистских стереотипов традиционалистского сознания рабочих), раньше всех осознав огромный манипуляционный потенциал профдвижения. Они действительно использовали революционное творчество масс, структурировав, оформив и канализировав спонтанные проявления профсоюзной демократии в интересах поддержания собственного господства.

Эксперимент рабочей демократии был изначально обречен на провал: сам ее эмбрион был нежизнеспособен и, вероятно, оказался мертворожденным. Зерно бюрократической трансформации и централизации революционных профсоюзов коренилось в их природе спонтанных органов общественной саморегуляции в условиях социального кризиса, не способных в принципе к конструктивному управлению экономикой и обществом. Подтверждая железный закон олигархии P. Михельса [Michels 1989], данный эксперимент наглядно продемонстрировал легкость превращения спонтанных форм непосредственной демократии в тиранию.

Будучи формой социальной утопии, данный эксперимент исходил, возможно, из романтических революционных ожиданий и благих намерений, но заложил основы той формальной и безжизненной советской бюрократической машины, последствия которой в полной мере не преодолены до настоящего времени. 


\section{Литература}

Венедиктов А.В. (1957) Организация государственной промышленности в СССР. Т. 1 (1917-1920). Л.: ЛГУ.

Виноградов В.А. (1983) Рабочий контроль над производством: теория, история, современность. М.: Наука.

Вопросы труда в СССР (1958). М.: Госполитиздат.

Гарви П.А. (1958) Профсоюзы в России (1917-1921). Нью-Йорк: Фонд по изданию литературного наследия П.А. Гарви.

Гимпельсон Е.Г. (1974) Советский рабочий класс 1918-1920 гг. Социально-политические измерения. М.: Наука.

Городецкий Е.Н. (1987) Рождение советского государства 1917-1918. М.: Наука.

Далин Д. (1922) После войн и революций. Берлин: Обелиск.

Загорский С. (1925) Рабочий вопрос в Советской России. Прага: Свободная Россия.

Игнатенко Т.А. (1971) Советская историография рабочего контроля и национализации промышленности в СССР (1917-1967 гг.). М.: Наука.

Казаков Р.Б., Румянцева М.Ф. (ред.) (2011) Когнитивная история. Концепция, методы, исследовательские практики. М.: РГГУ.

Крицман Л. (1924) Героический период Великой русской революции (опыт анализа так называемого «военного коммунизма»). М.: Госиздат.

Ларин Ю. (1920) Очерки хозяйственного развития советской России. М.: Госиздат.

Липсет С.М. (2015) Политические процессы в профсоюзах // Липсет С.М. Политический человек. Социальные основания политики. Гл. 12. М.: Мысль. С. 423-470.

Ломов А. (1918) Разложение капитализма и организация коммунизма. М.: ВСНХ.

Медушевский А.Н. (2013) Феномен большевизма: логика революционного экстремизма с позиций когнитивной истории // Общественные науки и современность. № 5-6. С. 111-120.

Медушевский А.Н. (2015) Миф Коммуны и становление Советского государства (К переосмыслению Конституции РСФСР 1918 года) // Общественные науки и современность. № 4. С. 121-140.

Медушевский А.Н. (2017) Политическая история русской революции: нормы, институты, формы социальной мобилизации в XX веке. М.-СПб.: Центр гуманитарных инициатив.

Милюков П.Н. (1921) История второй русской революции. Т. 1. Вып. 1-3. София: Российско-болгарское книгоиздательство.

Милютин В.П. (1918) Современное экономическое развитие России и диктатура пролетариата (1914-1918). М.: Госиздат.

Осинский Н. (В.В.Оболенский) (1918) Строительство социализма. Общие задачи. Организация производства. М.: Госиздат.

Панкратова А.М. (ред.) (1954) История профсоюзного движения в СССР. М.: Профиздат.

Прокопович С.Н. (1923) Очерки хозяйства Советской России. Берлин: Обелиск.

Рогачевская Л.С. (1973) Ликвидация безработицы в СССР 1917-1930. М.: Наука.

Рожков Н. (1926) Русская история в сравнительно-историческом освещении (Основы социальной динамики). Т. 12. М.-Л.: Книга.

Солженицын А.И., Бернштам М.С. (ред.) (1981) Независимое рабочее движение в 1918 г. Документы и материалы. Париж: IMCA-PRESS.

Струве П. (1921) Размышления о русской революции. София: Российско-болгарское книгоиздательство.

Суханов Н. (1923) Записки о революции. Кн. 4. Берлин-Петербург-Москва: Изд. З.И. Гржебина.

Тейлор Ф.У. (1925) Научная организация труда. М.: НКПС.

Фин Я. (1922) Фабрично-заводские комитеты в России. М.: ВЦСПС.

Цыперович Г. (1921) Рабочий контроль и фабрично-заводские комитеты (Речи и резолюции 1-го Международного конгресса Профинтерна). М.: Отдел печати Профинтерна.

Чураков Д. О. (2007) Бунтующие пролетарии: рабочий протест в советской России (1917-1930-е гг.). М.: Вече.

Шарапов Г.В. (ред.) (1977) История профсоюзов в СССР. М.: Профиздат. 
Шкаратан О.И. (2012) Социология неравенства. Теория и реальность. М.: ВШЭ.

Avrich P.H. (1963) The Bolshevik Revolution and Worker's Control in Russian Industry // Slavic Review, no 3, pp. 48-60.

Brinton M. (1970) The Bolsheviks and Worker's Control 1917 to 1921 . The State and CounterRevolution, London: Black Rose.

Brügmann U. (1972) Die russische Gewerkschaften in Revolution und Bürgerkrieg 1917-1919, Frankfurt am Main: Europaische Verlagsanstalt.

Carr E.H. (1985) The Bolshevik Revolution, 1917-1923. Vol. 2, N.Y.: W.W. Norton and Company, pp. 78-79.

Conquest R. (1967) Industrial Workers in the USSR, London: Bodley Head.

Dunn R.W. (1928) Soviet Trade Unions, N.Y.: Vanguard.

Kaplan F. (1968) Bolshevik Ideology and the Ethics of Soviet Labor, 1917-1920, N.Y.: Philosophical Library.

Kaytsky K. (1918) Die Dictatur des Proletariats, Wien: Brand.

Koch W. (1932) Die bolschevistischen Gewerkschaften. Eine herrschaftssoziologische Studie, Jena: Gustav Fischer.

Michels R. (1989) Zur Soziologie des Parteiwesens in der Modernen Democratie. Untersuchungen über die Oligarchischen Tendenzen des Gruppenlebens, Stuttgart.

Pirani S. (2008) The Russian Revolution in Retreat, 1920-24. Soviet Workers and the New Communist Elite, London: Routledge.

Prokopovich S.N. (1924) The Economic Conditions of Soviet Russia, London: King and Son.

Sorenson J.B. (1969) The Life and Death of Soviet Tradeunionism. 1917-1928, N.Y.: Atherton Press.

\title{
The Communal State: an Experiment in Workers' Democracy in Russia in 1918 and Its Failure
}

\author{
A. MEDUSHEVSKIY*
}

*Andrei Medushevskiy - DSc in Philosophy, Tenure Professor, Faculty of Social Sciences, National Research University Higher School of Economics. Address: 20, Myasnitskaya St., Moscow, 101000, Russian Federation. E-mail: amedushevsky@mail.ru

Citation: Medushevskiy A. (2019) The Communal State: an Experiment in Workers' Democracy in Russia in 1918 and Its Failure. Mir Rossii, vol. 28, no 2, pp. 63-83 (in Russian). DOI: $10.17323 / 1811-038 X-2019-28-2-63-83$

\begin{abstract}
The utopian Communist ideal of a workers' state, which was put into action after the Bolshevik takeover of power in Russia in 1917, provoked new types of social mobilization, adaptation, and domination and new political institutions. At the core of this experiment was the new concept of Labor Unions as a form of intermediate democracy which could potentially be transformed into a communal state based on the collective production and distribution of property, wealth, and social responsibility between broad nets of workers unions.
\end{abstract}


In the sociological literature and international historiography, this social experiment was scrutinized as a rare or even unique historical example of how the abstract syndical concept of a stateless society (based on cooperation and solidarity rather than on bureaucratic control) could be put into reality. This form of self-government was interpreted as a substantive historical alternative to the traditional "bourgeois" state with its key institutions - parliamentarianism, the separation of powers and an independent judicial system. In some current left-oriented theories, this is considered a "model" experiment - successful, consecutive and effective in its initial stage (in the period of the so-called "War Communism" in 1918-20), but revised and finally rejected in the following period of bureaucratic Communism with its one-party hegemony and Stalinist dictatorship. In order to understand the scientific value of such statements, the author provides a detailed analysis of the principles, initial forms and implications of Soviet labor self-government in the early formation period (1918), using multiple primary sources - the minutes and protocols of central and local labor unions, the old and the new ones, which depict the social, professional, and administrative stratification of Russian revolutionary society during its formation.

The author's central argument is that the so-called deterioration of labor selfgovernment in Soviet Russia was rooted mainly in the internal transformation of unions as formal organizations rather than external pressure or strategic mistakes. From the very beginning the revolutionary labor unions were different from the typical Western social democratic unions - they had a different, more traditional, social background, and sought a different role in social transformation. A combination of internal and external factors in this transformation created the institutional basis for a new type of social inequality, the development of oligarchic trends in Soviet labor unions, and the formation of a new "labor bureaucracy". The Bolshevist party exploited these trends but did not generate them. In other words, the whole experiment in workers' democracy from its very beginning was profoundly unrealizable and belongs to the museum of human utopian social projects.

Key words: Russian revolution, communism, syndicalism, anarchism, social utopia, workers' democracy, labor unions, labor conflicts, social mobilization, social stratification, protest, deviations, repressions, hierarchy, oligarchy, bureaucracy, masses and leaders

\section{References}

Avrich P.H. (1963) The Bolshevik Revolution and Worker's Control in Russian Industry. Slavic Review, no 3, pp. 48-60.

Brinton M. (1970) The Bolsheviks and Worker's Control 1917 to 1921. The State and Counterrevolution, London: Black Rose.

Brügmann U. (1972) Die russische Gewerkschaften in Revolution und Bürgerkrieg 1917-1919, Frankfurt am Main: Europaische Verlagsanstalt.

Carr E.H. (1985) The Bolshevik Revolution, 1917-1923. Vol. 2, N.Y.: W.W. Norton and Company, pp. $78-79$.

Churakov D.O. (2007) Buntuyushchie prolitarii: rabochij protest v sovetskoj Rossii (1917-1930) [Rebellious Proletariat: The Workers' Protest in Soviet Russia (1917-1930)], Moscow: Veche. 
Conquest R. (1967) Industrial Workers in the USSR, London: Bodley Head.

Dalin D. (1922) Posle vojn i revolutsii [After Wars and Revolutions], Berlin: Obelisk.

Dunn R.W. (1928) Soviet Trade Unions, N.Y.: Vanguard.

Fin Ya. (1922) Fabrichno-zavodskie komitety v Rossii [Workers' Committees in Russia], Moscow: VCSPS

Garvi P.A. (1958) Profsoyuzy v Rossii (1917-1921) [Trade Unions in Russia (1917-1921)], NewYork: Fond po izdaniyu literaturnogo naslediya P.A. Garvi.

Gimpelson E.G. (1974) Sovetskij rabochij klass, 1918-1920 z2. Sotsial'no-politicheskie izmerenya [The Soviet Working Class, 1918-1920. The Socio-political Dimensions], Moscow: Nauka.

Gorodetskij E.Kh. (1987) Rozhdenie sovetskogo gosydarstva, 1917-1918 [The Birth of the Soviet State, 1917-1918], Moscow: Nauka.

Ignatenko T.A. (1971) Sovetskaya istoriografiya rabochego kontrolya $i$ natsionalisatsii promyshlennosti v SSSR (1917-1967 22.) [The Soviet Historiography of the Worker's Control and the Nationalization of Industry in USSR, 1917-1967], Moscow: Nauka.

Kaplan F. (1968) Bolshevik Ideology and the Ethics of Soviet Labor, 1917-20, N.Y.: Philosophical Library.

Kaytsky K. (1918) Die Dictatur des Proletariats, Wien: Brand.

Kazakov R.B., Rumyantseva M.F. (eds.) (2011) Kognitivnaya istoria. Kontseptsiya, metody, issledovatel'skie praktiki [Cognitive History. Concept, Methods, and Research Practices], Moscow: RGGU.

Koch W. Die bolschevistischen Gewerkschaften. Eine herrschaftssoziologische Studie, Jena: Gustav Fischer.

Kritsman L. (1924) Geroicheskij period velikoj russkoj revolutsii (opyt analiza tak nazyvaemogo "voennogo kommunizma") [The Heroic Period of the Great Russian Revolution (an Experience in Investigation of the So-called "Military Communism"], Moscow: Gosizdat.

Larin Yu. (1920) Ocherki khozyajstvennogo razvitiya Sovetskoj Rossii [A Study of Soviet Economic Development], Moscow: Gosizdat.

Lipset S.M. (2015) Politicheskie protsessy v profsoyuzach [Political Processes in Trade Unions]. Lipset S.M. Politicheskij chelovek. Sotsial'nye osnovaniya politiki. Gl. 12 [The Political Man. The Social Bases of Politics. Ch. 12], Moscow: Mysl', pp. 423-470.

Lomov A. (1918) Razlozhenie kapitalizma i organizatsiya komunizma [The Destruction of Capitalism and the Organization of Communism], Moscow: VSNH.

Medushevskiy A.N. (2013) Fenomen bolshevizma: logika revoluzionnogo extremizma s posizii kognitivnoj istorii [The Phenomenon of Bolshevism: the Logic of Revolutionary Extremism as a Subject of Cognitive History Studies]. Obshchestvennye nauki i sovremennost', no 5-6, pp. 111-120.

Medushevskiy A.N. (2015) Mif Communy i stanovlenie Sovetskogo gosudarstva [The Myth of Paris Commune and the Creation of the Soviet State]. Obshchestvennye nauki i sovremennost', no 4, pp. 121-140.

Medushevskiy A.N. (2017) Politicheskaya istoriya russkoj revolutsii: normy, instituty, formy sotsial'noj mobilizatsii v XX veke [The Political History of the Russian Revolution: Norms, Institutions and Forms of Social Mobilization in XX Century], Moscow-Petersburg: Zentr gumanitarnych initsiativ.

Michels R. (1989) Zur Soziologie des Parteiwesens in der Modernen Democratie. Untersuchungen über die Oligarchischen Tendenzen des Gruppenlebens, Stuttgart.

Milukov P.N. (1921) Istoriya vtoroj russkoj revolutsii. T. 1. Vyp. 1-3 [The History of the Second Russian Revolution. Vol. 1. Issues 1-3], Sofia: Russko-bolgarskoe knigoizdatelstvo.

Milutin V.P. (1918) Sovremennoe ekonomicheskoe razvitie Rossii $i$ diktatura proletariata (1914-1918) [The Contemporary Economic Development of Russia and the Dictatorship of Proletariat, 1914-1918], Moscow: Gosizdat.

Osinskij N. (V.V.Obolenskij) (1918) Stroitel'stvo sotsialisma. Obschie zadachi. Organizatsiya proizvodstva [The Building of Socialism. General Goals. Organization of Production], Moscow: Gosizdat.

Pankratova A.M. (ed.) (1954) Istoriya profsoyuznogo dvizheniya v SSSR [The History of Trade Unions Movement in USSR], Moscow: Profizdat. 
Pirani S. (2008) The Russian Revolution in Retreat, 1920-24. Soviet Workers and the New Communist Elite, London: Routledge.

Prokopovich S.N. (1923) Ocherki khozyajstva Sovetskoj Rossii [A Study of the Soviet Economic System], Berlin: Obelisk.

Prokopovich S.N. (1924) The Economic Conditions of Soviet Russia, London: King and Son.

Rogachevskaya L.S. (1973) Likvidatsiya bezrabotitsy v SSSR 1917-1930 [The Liquidation of Unemployment in USSR 1917-1930], Moscow: Nauka.

Rozhkov N. (1926) Russkaya istoriya v sravnitel'no-istoricheskom izlozhenii (Osnovy sotsial'noj dinamiki). T. 12 [Russian History in Comparative-historical Explanation (The Bases of Social Dynamics). Book 12], Moscow-Leningrad: Kniga.

Sharapov G.V. (ed.) (1977) Istoriya profsoyuzov v SSSR [The History of Trade Unions in USSR], Moscow: Profizdat.

Shkaratan O.I. (2012) Sotsiologiya neravenstva. Teoriya i real'nost' [Sociology of Inequality. Theory and Reality], Moscow: HSE.

Solzhenitsin A.I., Bernstam M.S. (eds.) (1981) Nezavisimoe rabochee dvizhenie v $1918 \mathrm{~g}$. Dokumenty i materialy [The Independent Workers' Movement in 1918. Documents and Materials], Paris: IMCA-PRESS.

Sorenson J.B. (1969) The Life and Death of Soviet Tradeunionism. 1917-1928, N.Y.: Atherton Press.

Struve P. (1921) Razmyshleniya o russkoj revolutsii [Reflections on the Russian Revolution], Sofia: Russko-bolgarskoe knigoizdatelstvo.

Sukhanov N. (1923) Zapiski o revolutsii. Kn. 4. 1922-1923 [Notes on the Revolution. Book 4. 1922-1923], Berlin-Petersburg-Moscow: Z.I.Grzebin.

Tailor F. (1925) Nauchnaya organizatsiya truda [The Scientific Organization of Labor], Moscow: NKPS.

Tsyperovich G. (1921) Rabochij kontrol' i fabrichno-zavodskie komitety (rechi i rezoliuzii 1-go Mezhdunarodnogo kongressa Profinterna) [The Workers' Control Committies (Speeches and Resolutions of the 1-st International Congress of Profintern)], Moscow: Profintern.

Venediktov A.V. (1957) Organizatsiya gosudarstvennoj promyshlennosti v SSSR. T. 1 (1917-1920) [The Organization of State Industry in the USSR. Vol. 1. (1917-1920)], Leningrad: LGU.

Vinogradov V.A. (1983) Rabochij kontrol' nad proizvodstvom: teoriya, istoriya, sovremennost' [The Workers' Control over Production: Theory, History, Contemporary Situation], Moscow: Nauka.

Voprosy truda v SSSR (1958) [Labor Issues in USSR], Moscow: Gospolitizdat.

Zagorskij S. (1925) Rabochij vopros v Sovetskoj Rossii [The Workers' Question in Soviet Russia], Praha: Svobodnaya Rossiya. 